\section{Competence for In Vitro Bulblet Regeneration among Eight Lilium Genotypes}

\author{
Laura R. Bahr and Michael E. Compton ${ }^{1}$ \\ School of Agriculture, 1 University Plaza, University of Wisconsin-Platteville, \\ Platteville, WI 53818
}

Additional index words. lily, micropropagation, tissue culture

\begin{abstract}
Competence for in vitro bulblet regeneration was investigated for eight diverse Lilium genotypes ( $L$. 'Citronella', $L$. 'Stargazer', L. 'Stones', L. 'Lovely Girl', L. pumilum, L. lancifolium, L. lancifolium 'Orange Star', and L. speciosum var. rubrum). Explants established from bulb scales were cultured on lily bulblet regeneration medium [Murashige and Skoog (1962) modified by reducing the $\mathrm{NH}_{4} \mathrm{NO}_{3}$ to $0.825 \mathrm{~g} \cdot \mathrm{L}^{-1}$ and $\mathrm{KH}_{2} \mathrm{PO}_{4}$ to 0.170 $\mathrm{g} \cdot \mathrm{L}^{-1}$, and adding (per liter) $30 \mathrm{~g}$ sucrose, $0.1 \mathrm{~g}$ myoinositol, $0.4 \mathrm{mg}$ thiamine $\cdot \mathrm{HCl}, 80 \mathrm{mg}$ adenine sulfate, $16 \mu \mathrm{M}$ naphthaleneacetic acid, $2 \mathrm{~mL} \cdot \mathrm{L}^{-1}$ Plant Preservative Mixture (PPM), and $4.5 \mathrm{~g} \cdot \mathrm{L}^{-1}$ AgarGel at $\mathrm{pH}$ 5.7] for 8 weeks before transfer to sphagnum peat moss and 4 weeks refrigeration at $5{ }^{\circ} \mathrm{C}$ in darkness. All genotypes produced bulblets in vitro. However, the response rate varied among genotypes. Explants of Lilium 'Lovely Girl', $L$. 'Citronella', and $L$. speciosum var. rubrum were most responsive with $\approx 90 \%$ producing bulblets. The number of bulblets per responding explant ranged from 5.2 ('Stones') to 2.3 (L. lancifolium). When comparing in vitro and greenhouse bulblet production, about twice as many bulblets were produced by explants in vitro compared to halved scales incubated in the greenhouse. The percentage of responding explants ranged from $33 \%$ to $360 \%$ greater for six of the genotypes tested when propagated in vitro compared to bulb scales propagated in the greenhouse. Following refrigeration, bulblets were transferred to the greenhouse for sprouting. Over $80 \%$ of bulblets obtained from $L$. 'Citronella', $L$. lancifolium 'Orange Star', L. lancifolium, and $L$. 'Stones' sprouted in the greenhouse. This study illustrates that a diverse range of lily species can be successfully propagated in vitro using a single medium formulation and is the first report of bulblet regeneration in vitro for $L$. 'Citronella', $L$. 'Stones', L. 'Lovely Girl', and $L$. lancifolium 'Orange Star'.
\end{abstract}

Plants within the genus Lilium are highly prized by horticulturists because of their outstanding fragrance, range of color, hardiness, and adaptability to varied environmental conditions. Lilies are cultivated commercially for cut flowers or potted plants (Larson, 1992), and for aesthetic purposes in the home garden (Hermes, 1986). There are hundreds of lily species and hybrids available to horticulturists world-wide(Armitage, 1997). For horticultural use, lilies had been divided into 10 divisions of closely related taxa and hybrids, including Asiatic, Martagon, Candidum, American, Longiflorum hybrids (L. longiflorum x Asiatic), Chinese Trumpet and Aurelian hybrids, Oriental, Orienpet hybrids (Chinese Trumpet and Aurelian hybrids x Oriental), True species and miscellaneous hybrids (hybrids not included in any of the other divisions) (McRae, 1998). Asiatic, Oriental, Trumpet, Orienpet, Martagons, and Easter lily (L. longiflorum) are the most popular among avid lily fanciers (Armitage, 1997).

Lilies are propagated vegetatively to preserve their genetic integrity (Armitage, 1997). Propagules include bulb scales, division of plants and bulblets, or planting of

Received for publication 28 Aug. 2003. Accepted for publication 9 Oct. 2003.

${ }^{1}$ Associate Professor; to whom reprint requests should be addressed.E-mail: compton@uwplatt.edu bulbils. Because of slow propagation rates and the potential for transmission of diseases using traditional propagation techniques, tissue culture has been touted as a way to rapidly produce disease-free plants using bulb scales (Stimart et al., 1982, 1983), shoot apices (Mii et al., 1994), or leaves (Kato and Yasutake, 1977; Niimi, 1986). More recently, plants have been regenerated from thin cell layer explants derived from receptacle, leaf, and stem tissue of L. longiflorum (Nhut et al., 2001). Most successful examples of in vitro regeneration of Lilium have been reported among L. longiflorum genotypes, with limited regeneration being reported for other popular Lilium species (Nhut et al., 2001). The purpose of this study was to investigate the feasibility of regenerating bulblets in vitro from bulb scale explants of eight diverse Lilium genotypes using a single regeneration medium, and to determine if previously undocumented genotypes ( $L$. 'Citronella', $L$. lancifolium 'Orange Star', L. 'Stones', and $L$. 'Lovely Girl') can be regenerated in vitro using standard techniques for lily.

\section{Materials and Methods}

Plantmaterials and culture initiation. Bulbs of eight Lilium genotypes ( $L$. 'Citronella'; $L$. 'Lovely Girl', L. 'Stargazer', and L. 'Stones'; L. pumilum; two genotypes of L. lancifolium - 'Orange Star' and the true species; and $L$. speciosum var. rubrum) were obtained from
Van Bourgondien, Inc. (Babylon, N.Y.) during Apr. 2001. Bulbs were planted in 15-cm standard plastic pots containing soilless medium (Fafard No. 3, Anderson, S.C.) and grown in the greenhouse until conditions permitted transplanting to the horticulture garden at the Univ. of Wisconsin-Platteville (UWP) (June 2001). Bulbs were dug at two sampling dates (3 and 29 Oct. 2001) with each sampling date representing a replication in time. All outer scales and diseased or damaged scales were removed and discarded. Individual bulb scales were washed in warm water and the distal half of each scale discarded, leaving the proximal 1 to $1.5 \mathrm{~cm}$ in closest contact to the main stem. Trimmed scales were washed with soapy (Equate antibacterial soap) tap water until all loose soil particles were removed, and then rinsed in tap water, followed by a brief distilled water rinse. Washed bulb scale pieces were agitated in a $10 \%$ bleach solution $\left(0.6 \% \mathrm{NaOCl}\right.$ plus $2 \mathrm{~mL} \cdot \mathrm{L}^{-1}$ Equate antibacterial soap) for $20 \mathrm{~min}$, followed by three rinses with sterile distilled water.

Small $(5 \times 5 \mathrm{~mm})$ explant cubes were prepared from the basal edge of disinfested bulb scales and cultured for 8 weeks in $15 \times 125$ $\mathrm{mm}$ culture tubes containing $15 \mathrm{~mL}$ of Lilium bulblet regeneration medium [Murashige and Skoog (1962) modified by reducing the $\mathrm{NH}_{4} \mathrm{NO}_{3}$ to $0.825 \mathrm{~g} \cdot \mathrm{L}^{-1}$ and $\mathrm{KH}_{2} \mathrm{PO}_{4}$ to 0.170 $\mathrm{g} \cdot \mathrm{L}^{-1}$, and adding (per liter) $30 \mathrm{~g}$ sucrose, 0.1 $\mathrm{g}$ myoinositol, $0.4 \mathrm{mg}$ thiamine $\cdot \mathrm{HCl}, 80 \mathrm{mg}$ adenine sulfate, $16 \mu \mathrm{M}$ naphthaleneacetic acid as prescribed by Kyte \& Kleyn (1996)]. Plant Preservative Mixture (Plant Cell Technology, Inc., Washington, D.C.) $\left(2 \mathrm{~mL} \cdot \mathrm{L}^{-1}\right)$ was added before adjusting the medium $\mathrm{pH}$ (5.7) and adding $4.5 \mathrm{~g} \cdot \mathrm{L}^{-1}$ AgarGel (Phytotechnology Laboratories, Shawnee Mission, Kans.). A single explant was cultured per vessel and all vessels incubated in darkness at $27^{\circ} \mathrm{C}$. Vessels were arranged in a completely randomized design with 20 replicates per genotype. The experiment was conducted twice.

Regeneration of bulblets in greenhouse conditions. A separate group of bulb scales were planted in the greenhouse at the same time that in vitro cultures were established. Twenty bulb scale halves $(30 \mathrm{~mm}$ high $\times 20$ mm wide) of each genotype were placed in 13.3 $\times 8.8 \times 5.4 \mathrm{~cm}$ plastic containers containing soilless medium (Fafard No.3) with the basal 1 to $1.5 \mathrm{~cm}$ placed below the surface of the medium. Propagules were arranged in a completely randomized design. The propagation medium was irrigated with tap water when dry to the touch.

Cold treatment of regenerated bulblets and transfer to the greenhouse. In vitro- and greenhouse-derived bulblets were transplanted to six-cell containers $(13.3 \times 8.8 \mathrm{~cm}$ plastic containers with six $82-\mathrm{cm}^{3}$ cells; COM-PACKS \#806, Hummert Intl., Earth City, Mo.) filled with sphagnum peat moss and refrigerated at $5{ }^{\circ} \mathrm{C}$ in darkness for 4 weeks. Bulblets were irrigated with distilled water when dry to the touch. Refrigerated bulblets were sprouted in the greenhouse and observed for 5 months.

Data collection and statistical analysis. Data included the number and percentage of 
Table 1. Percentage of in vitro bulb scale explants that produced callus, percentage of in vitro explants and greenhouse propagules that produced bulblets, number of bulblets per in vitro explant and greenhouse propagule, and percentage of bulblets from in vitro explants and greenhouse propagated bulb scales of eight Lilium genotypes that sprouted in the greenhouse following cold treatment. ${ }^{2}$

\begin{tabular}{|c|c|c|c|c|c|c|c|}
\hline \multirow[b]{2}{*}{ Genotype } & \multirow{2}{*}{$\begin{array}{l}\text { Explants } \\
\text { with callus } \\
(\%)\end{array}$} & \multicolumn{2}{|c|}{ Explants with bulblets ${ }^{\mathrm{x}}(\%)$} & \multicolumn{2}{|c|}{ Bulblets per responding explant $^{\mathrm{w}}$} & \multicolumn{2}{|c|}{ Bulblets that sprouted ${ }^{\mathrm{v}}(\%)$} \\
\hline & & In vitro & Greenhouse & In vitro & Greenhouse & In vitro & Greenhouse \\
\hline L. 'Citronella' & $21 \mathrm{bc}$ & $90 \mathrm{a}$ & $60 \mathrm{bc}$ & $2.5 \mathrm{~cd}$ & $1.3 \mathrm{e}$ & $92 \mathrm{a}$ & $46 \mathrm{~b}$ \\
\hline L. 'Lovely Girl' & 95 a & $90 \mathrm{a}$ & $25 \mathrm{e}$ & $3.6 \mathrm{~b}$ & $1.4 \mathrm{e}$ & $19 \mathrm{bc}$ & $14 \mathrm{bc}$ \\
\hline L. 'Stargazer' & $76 \mathrm{a}$ & $62 \mathrm{bc}$ & $25 \mathrm{e}$ & $2.8 \mathrm{~cd}$ & $1.2 \mathrm{e}$ & $8 \mathrm{c}$ & $50 \mathrm{~b}$ \\
\hline L. 'Stones' & $8 \mathrm{c}$ & $22 \mathrm{e}$ & $85 \mathrm{a}$ & $5.3 \mathrm{a}$ & $2.5 \mathrm{~cd}$ & $78 \mathrm{a}$ & $33 \mathrm{~b}$ \\
\hline L. lancifolium & $15 \mathrm{bc}$ & $65 \mathrm{bc}$ & $30 \mathrm{de}$ & $2.3 \mathrm{~d}$ & $1.5 \mathrm{e}$ & $77 \mathrm{a}$ & $88 \mathrm{a}$ \\
\hline L. lancifolium 'Orange Star' & $34 \mathrm{~b}$ & $77 \mathrm{ab}$ & $50 \mathrm{~cd}$ & $2.5 \mathrm{~cd}$ & $1.3 \mathrm{e}$ & $88 \mathrm{a}$ & $75 \mathrm{a}$ \\
\hline L. pumilum & $9 \mathrm{c}$ & $63 \mathrm{bc}$ & $65 \mathrm{bc}$ & $3.0 \mathrm{c}$ & $2.3 \mathrm{~d}$ & $12 \mathrm{c}$ & $0 \mathrm{~d}$ \\
\hline L. speciosum var. rubrum & $86 \mathrm{a}$ & $86 \mathrm{a}$ & $35 \mathrm{de}$ & $2.9 \mathrm{~cd}$ & $1.3 \mathrm{e}$ & $30 \mathrm{~b}$ & $25 \mathrm{bc}$ \\
\hline
\end{tabular}

${ }^{2}$ Data from both runs of the experiment were not significantly different and pooled before analysis. Means with the same letter from in vitro and greenhouse propagules are not significantly different according to Tukey's Honestly Significantly Different test at $P<0.05$. Percentage data were transformed using arc sin before analysis. However, the actual means are presented.

yPercentage of bulb scale explants that formed callus in vitro.

xPercentage of in vitro bulb scale explants and halved bulb scales incubated in the greenhouse that produced bulblets.

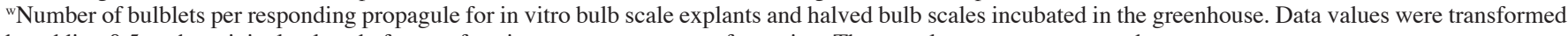
by adding 0.5 to the original values before performing a square root transformation. The actual means are presented.

vercentage of in vitro-derived bulblets that sprouted in the greenhouse following refrigeration at $5{ }^{\circ} \mathrm{C}$ for 4 weeks.

explants that produced callus, the number and percentage of explants that formed bulblets, and the number of bulblets per responding explant 8 weeks after culture initiation, or onset of incubation in the greenhouse. Percentage data were analyzed using logistic regression and count data analyzed using Poisson regression (Mize et al., 1999). Treatment means of percentage data were transformed using arc sin transformation before analysis, using Tukey's Honestly Significant Test (Tukey's HSD). Count data (number of bulblets per responding explant) were transformed by adding 0.5 to each data value before performing square root transformation (Compton 1994) and analyzed using Tukey's HSD. Transformed data were converted back to the original scale for presentation.

\section{Results and Discussion}

The percentage of explants producing bulblets and the number of bulblets per explant were similar among the sampling dates. Therefore, data for the two runs were pooled before analysis.

All eight genotypes tested produced callus with 'Lovely Girl', L. speciosum var. rubrum, and 'Stargazer' being the most prolific (Table 1). The least prolific callus producers were $L$. pumilum and 'Stones', with fewer than $10 \%$ of explants producing calli. Callus formation frequencies observed in this study were similar to observations reported for other Lilium taxa (Godo and Mii, 2001). However, we observed that $9 \%$ to $34 \%$ of L. pumilum and L. lancifolium explants produced callus. In contrast, Pelkonen (1997) insinuated that L. pumilum and L. lancifolium explants were incapable of callus formation from any explant using similar pgr concentrations. Plant regeneration through adventitious shoot regeneration and somatic embryogenesis from callus or protoplast-derived callus has been demonstrated for several Lilium taxa (Nhut et al., 2001). However, due to the potential risk of chromosomal rearrangements and other mutations that commonly occur during regeneration from callus (Scowcroft, 1985; Veilleux and Johnson,
1998), we decided not to pursue indirect plant regeneration methods.

Explants from all eight genotypes produced bulblets in vitro (Table 1). However, the response rate varied among genotypes. About 90\% of 'Lovely Girl', L. 'Citronella' (Fig. $1 \mathrm{~A}$ ), and $L$. speciosum var. rubrum explants produced bulblets. About $60 \%$ to $80 \%$ of bulb scale explants collected from $L$. lancifolium 'Orange Star', L. lancifolium, L. pumilum, and 'Stargazer' regenerated bulblets, while fewer than $25 \%$ of 'Stones' explants produced bulblets.

In general, the percentage of propagules that produced bulblets in vitro $(67 \%)$ was greater than the amount produced by halved bulb scales in the greenhouse (47\%) for six of the eight genotypes tested $(P<0.0001)$. For these genotypes, the percentage of responding propagules was one-third to 3.6-fold greater for in vitro explants compared to those incubated in soilless medium in the greenhouse. This is a significant finding because twice as many propagules can be isolated from a single bulb scale for in vitro culture compared to traditional macropropagation procedures. There were two species for which greenhouse propagation was more efficient than in vitro production. Bulb scale propagules isolated from 'Stones' responded more efficiently (85\%) when incubated in the greenhouse compared to in vitro regeneration $(22 \%)$. The percentage of propagules that produced bulblets was equally efficient for L. pumilum regardless of the propagation environment.

The number of bulblets per responding explant in vitro ranged from 2.3 (L. lancifolium) to 5.2 (Table 1). Although the number of bulblets per explant was highest for $L$. 'Stones', the percentage of responding explants was low (22\%) for this genotype. Therefore, $L$. 'Stones' should not be considered a genotype with exceptional competence for bulblet regeneration. Among genotypes with a high response rate, $L$. 'Lovely Girl' explants produced both a high number of bulblets per responding explant (3.6) and a high competence (90\%). When comparing in vitro and greenhouse bulblet regeneration, the number of bulblets per propagule was greater for all genotypes when bulb scale pieces were cultured in vitro compared to soilless medium in the greenhouse (Table 1). On average, explants cultured in vitro produced $\approx 1.7$-fold more bulblets per propagule compared to halved bulb scales incubated in the greenhouse (2.9 vs. 1.7, respectively). This is again significant because of the small size ( 5 $\times 5 \mathrm{~mm}$ ) of in vitro explants, which were less than half the size of halved bulb scales used for greenhouse propagation.

Bulblets from all eight genotypes sprouted in the greenhouse following refrigeration at 5 ${ }^{\circ} \mathrm{C}$ in darkness. However, differences in plant development were observed among bulblets derived from the two propagation environments (Table 1). About $90 \%$ of in vitro-derived $L$. 'Citronella' and L. lancifolium 'Orange Star' bulblets sprouted, and just under $80 \%$ of bulblets regenerated from L. lancifolium and 'Stones' developed into plants. Fewer than $30 \%$ of in vitro-derived bulblets from $L$. speciosum var. rubrum, L. pumilum, 'Lovely Girl', and 'Stargazer' sprouted. Plant development from bulblets propagated from bulb scales incubated in the greenhouse was similar to in vitro sources for L. lancifolium, L. lancifolium 'Orange Star', 'Lovely Girl', and L. speciosum var. rubrum. Plant development was better from in vitro-derived bulblets for three of the taxa tested. Over twice as many $L$. 'Citronella' and $L$. 'Stones' in vitro-derived bulblets sprouted compared to greenhouse-derived bulblets, and none of the L. pumilum bulblets originating from the greenhouse sprouted compared to $12 \%$ sprouting observed for in vitro-derived bulblets. Sprouting of $L$. 'Stargazer' was better among bulblets derived from greenhouse than in vitro sources.

It is possible that longer incubation on regeneration medium and/or prolonging the cold treatment before transfer to the greenhouse could improve sprouting of bulblets regenerated in vitro from genotypes in which poor stem production was observed. Langens-Gerrits (1997) reported that only in vitro-derived bulblets weighing more than $150 \mathrm{mg}$ produced 

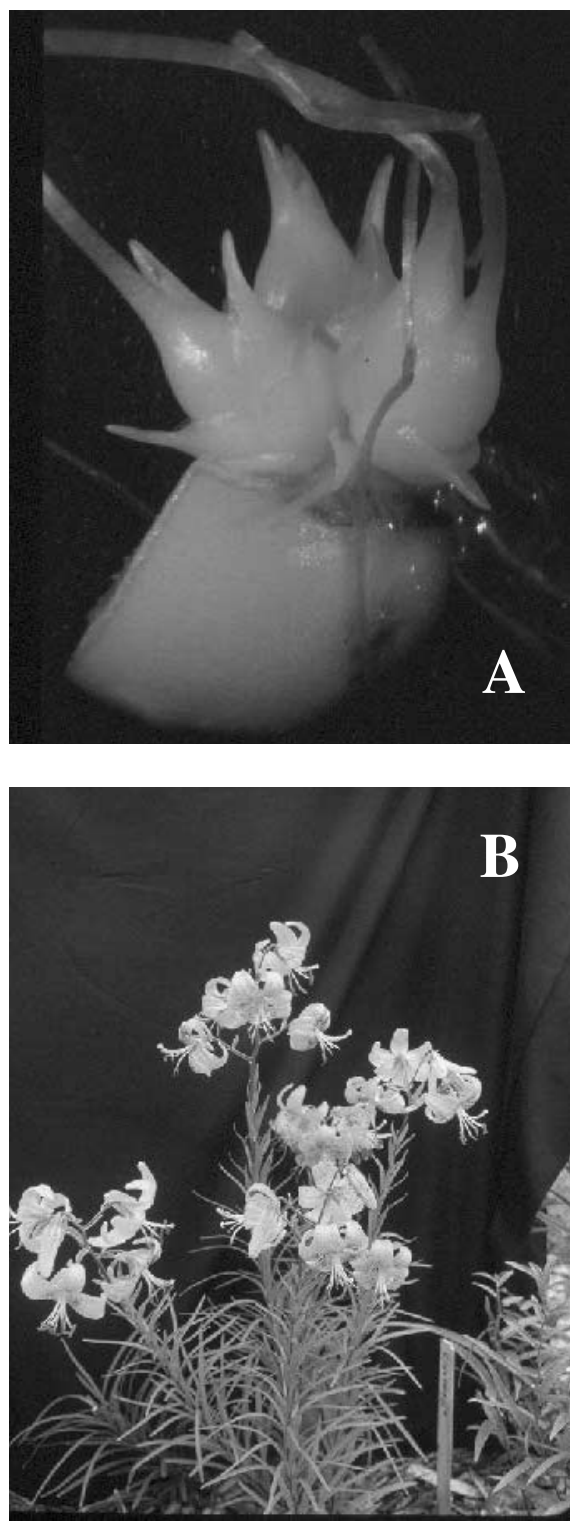

Fig. 1. (A) Lilium 'Citronella' bulb scale explants 8 weeks after initiation on regeneration medium. (B) Plants of $L$. 'Citronella' flowered within year after transplanting to outdoor conditions. stems with the greatest (70\%) stem formation occurring among bulblets that weighed $\approx 300$ $\mathrm{mg}(\mathrm{FW})$. Most of the bulblets regenerated in this study were small and may have weighed less than $150 \mathrm{mg}$ (data not shown). It is possible that lengthening the time on regeneration medium would allow bulblets to accumulate more starch and grow larger. Unfortunately, monitoring bulblet weight was not an objective of this study. Prolonging the cold treatment before sprouting in the greenhouse may also improve plant development. Stimart et al. (1982) observed that all in vitro-propagated L. longiflorum bulblets incubated at $25^{\circ} \mathrm{C}$ during regeneration sprouted following at least 2 weeks incubation at $4{ }^{\circ} \mathrm{C}$ before sprouting. In contrast, Takayama et al. (1982) observed that $70 \mathrm{~d}$ at $5{ }^{\circ} \mathrm{C}$ was required to achieve $100 \%$ leaf emergence and $3.3 \%$ bolting for in vitroderived bulblets of $L$. auratum. Likewise, Langens-Gerrits et al. (1997) used a 10-week cold treatment at $5{ }^{\circ} \mathrm{C}$ when studying plant development from in vitro-derived bulblets of $L$. 'Stargazer' and L. speciosum 'Rubrum no. $10^{\prime}$ '. We chose a 4-week cold treatment at $5^{\circ} \mathrm{C}$ because this time represents the midpoint of previously published reports.

Plants from all genotypes and regeneration environments were transplanted to the UWP horticulture gardens during June 2002. All plants grew vegetatively for the first season and flowered at the expected time during 2003 (Fig. 1B). No obvious signs of somaclonal variants were observed among plants regenerated in vitro or from greenhouse-propagated bulblets (data not shown).

Our study illustrates that a diverse range of lily species can be successfully propagated in vitro using a single medium formulation. In addition, we report for the first time successful in vitro regeneration of four Lilium genotypes (L. lancifolium 'Orange Star,' L. 'Citronella', $L$. 'Stones', and $L$. 'Lovely Girl') that were previously untested.

\section{Literature Cited}

Armitage, A.M. 1997. Herbaceous perennials plants: A treatise on their identification, culture and garden attributes. 2nd ed. Stipes Publ., Champaign, Ill.

Compton, M.E. 1994. Statistical methods suitable for the analysis of plant tissue culture data. Plant Cell Tiss. Org. Cult. 37:217-242.
Godo, T. and M. Mii. 2001. In vitro germplasm preservation of lily species utilizing callus cultures at low temperatures. Acta Hort. 560:153-155.

Hermes, A.R. 1986. Lilies that last. Horticulture 64:26-31.

Kato, Y. and Y. Yasutake. 1977. Plantlet formation and differentiation of epidermal tissue in green callus cultures from excised leaves of Lilium. Phytomorphology 27:390-396.

Kyte, L. and J. Kleyn. 1996. Plants from test tubes: An introduction to micropropagation. 3rd ed. Timber Press, Portland, Ore.

Langens-Gerrits, M., H. Lilien-Kipnis, T. Croes, W. Miller, C. Kollöffel, and G.-J. de Klerk. 1997. Bulb growth in lily regenerated in vitro. Acta Hort. 430:267-273.

Larson, R.A. 1992. Introduction to floriculture. Academic Press, New York.

McRae, E.A. 1998. Lilies: A guide for growers and collectors. Timber Press, Portland, Ore.

Mii, M., Y. Yuzawa, H. Suetomi, T. Motegi, and T. Godo. 1994. Fertile plant regeneration from protoplast of a seed-propagated cultivar of Lilium xformolongi by utilizing meristematic nodular cell clumps. Plant Sci. 100:221-226.

Mize, C.W., K.J. Koehler, and M.E. Compton. 1999. Statistical considerations for in vitro research: II. Data to presentation. In Vitro Cell. Dev. Biol.Plant 35:122-126.

Murashige, T. and F. Skoog. 1962. Arevised medium for rapid growth and bioassays with tobacco tissue cultures. Physiol. Plant. 15:473-497.

Nhut, D.T., B.V. Le, J.A. Teixeira da Silva, and C.R. Aswath. 2001. Thin cell layer culture system in Lilium: Regeneration and transformation perspectives. In Vitro Cell. Dev. Biol.-Plant 37:516-523.

Niimi, Y. 1986. Application of leaf segment culture to in vitro bulblets production of six Lilium species. Acta Bot. Neerl. 35:189-194.

Pelkonen, V.-P. 1997. Tissue culture as a means in the production of hardy lilies. Acta Hort. 447: 665-666.

Scowcroft, W.R. 1985. Somaclonal variation: The myth of clonal uniformity, p. 217-245. In: B. Hohn and E.S. Dennis (eds.). Genetic flux in plants. Springer-Verlag, Berlin.

Stimart, D.P., P.D. Ascher, and H.F. Wilkins. 1982. Overcoming dormancy in Lilium longiflorum bulblets produced in tissue culture. J. Amer. Soc. Hort. Sci. 107:1001-1007.

Stimart, D.P., P.D. Ascher, and H.F. Wilkins. 1983 Axis elongation from tissue-culture-generated bulblets of Lilium longiflorum Thunb. J. Amer. Soc. Hort. Sci. 108:99-101.

Veilleux, R.E. and A.A.T. Johnson. 1998. Somaclonal variation: Molecular analysis, transformation interaction and utilization. Plant Breed. Rev. 16:229-268. 